\title{
The Ecological Research of Ideological and Political Education in the Media Age ${ }^{1}$
}

\author{
Qin Meng \\ Yishui Yi County Road 28 city streets the Twins, Linyi University \\ Qinmeng2016hy@163.com
}

Keywords: Since the media; The ideological and political education; Ecological universities

\begin{abstract}
Because since the arrival of the current media era to the current Political Education in Colleges ring and internet have brought no small impact, it also allows the current academic circles began to explore new paths Campus Ideological Education Innovation Development, some scholars have proposed to ecosystem development into political education in colleges and universities were to change the inherent problems of traditional ideological and political education and promote their transition to the modernization of education. Foreign scholars on ideological and moral education is to explore more of the various factors that affect educational theories, models from the social point of view, focusing on the development of harmonized system of education, environment, social, cultural, ecological system from the perspective of risk factors to explore education and social internal relationship between environmental changes.
\end{abstract}

\section{Introduction}

In recent years, university political education Ecological Development has become a hot research subject, which also promoted the further development in the Campus Ideological Theory of ecological education to some extent, their studies focus and Political College education ecosystem to build a clear idea of the concept and feasibility analysis, although various research continues to diversify, but lack of systematic guidance of the concept, are inconclusive for the ideological and political education ecology concept, of course, continuing academic theory Follow ideological and political education but also to become cutting-edge issues of ecology education per discipline.

\section{The Media Age and Ideological and Political Education}

The Media Age. Under normal circumstances, people are talking about mainly refers to from the media, institutions, individuals concerned are able in various places, any period of time through various forms of links to the Internet, through the adoption of modern digital technology to link the world of science knowledge network, by expressing their true thoughts, ideas and other forms of real-time communication and exchanges, traditional from the media or it is generally used in the current we mainly take on, for example micro-channel, which the individual citizen, organs and units of the applications are very common. For self-concept media can be simply understood as it breaks through the limitations of traditional information and communication technology, more is to help people be able to use micro letter, micro-blog platform for information exchange and communication in their various electronic devices above, each individual in this case is basically an individual can be considered to be the most simple forms of media self. ${ }^{2}$

For from the media, usually containing the more prominent features several aspects: First, from the media and civilians with personalized features. Second, since the media has features easy operation. Third, since the media with interactive features and timeliness. Fourth, since the

\footnotetext{
${ }^{1}$ College of Humanities and social science research projects in Shandong Province (Special Political and Ideol ogical Education Research) University Ideological and Political Education Ecological Operations Research from media age; Item Number: J15YB10( 山 东省高校人文社会科学研究计划项目 (思想政治教育专题研究) 自媒体时代高等院校思想政治教育生态化运作研究; 项目编 号: J15YB10)

2 Luo Changqin from ecological Perspective Analysis of Chinese Marxism theoretical results and experience ecological evolution [J]. JOURNAL Heihe .2012 (03)
} 
development of the media is uneven.

Ideological and Political Education. In this study, access to relevant information, analysis found that people in the academic field of ideological and political education of the concept of ecological awareness is not enough unity, there are many different versions, which this study will be detailed analysis and definition to clarify the ideological and political ecological core content.

Through the analysis can be found in the so-called ideological and political education refers to study the ecology of institutions of higher learning ideological and political work related theories and concepts of modern ecological research system, through a comprehensive, systematic grasp and analysis to study the University Ideological and Political educational work related factors, identify existing problems and to propose targeted improvement strategies and recommendations, through coordination and balance between the factors, promoting university ideological and political education for sustainable development. ${ }^{3}$

\section{Analysis}

Current Ideological and Political Education Operating Mechanism Can Not Adapt to the Environment. Universities difficulty grasp of public opinion inside the lift. Since before the arrival of the media age, university ideological and political education of educators more traditional way, in a way mostly students at campus events, seminars and other topics, select the educational content is positive and healthy, problems arise with the conventional student the case is not complicated, but with the popularity of the platform from the media, these traditional educational methods difficult to adapt to the new changes in public opinion, and now the major colleges and universities in the relevant information from all kinds of media platforms has spread, which lack some of the false information, such information may be spread among college students, colleges and universities have some easily lead to negative emotions, then led to more intense teacher-student relationship, severe cases may result in the student population of the time, the current is more difficult to grasp for public opinion College, network supervision is also difficult to play a practical effect, the cumulative development of such negative emotions for students, the school and the community will be adversely affected. ${ }^{4}$

Multimedia platform in the past did not dominate the way colleges and universities for emerging public events and Mass times are cold treatment, which can be solved played down the negative consequences of enlargement. Colleges grasp the developments, control of the media initiative, the ability to affect the scope of immediate control. However, since the popularity of the media platform to break this situation, information dissemination between students more convenient, mobile media coming from the media age makes the dissemination of information presented geometric growth, which is also on the previous emergency response mechanism Universities huge impact, monitor the performance of colleges and universities to public opinion by the greater impact of past treatment may result in the loss of the best treatment time, which also increases the difficulty of ideological and political education of college students.

Current Ideological and Political Education Operating Mechanism Has Inherent Constraints. Universities traditional ideological and political education work. Campus Ideological education is the past with more specific topics, such education campaign also has a good effect, but because the interaction between teachers and students is insufficient education or limited to a single phase instill knowledge level is identity relationship educators and education topics are more specific, such a system has a certain balance. Since the media age to break the traditional ecological balance, no constraints and interactive information platform have stimulated the enthusiasm of college students to participate, college students receive information from passive to active, educators, the information conveyed is no longer education information the only source of

\footnotetext{
${ }^{3}$ Xiaoying Sheng, Zhang Yaocan New Thinking [J]. Teaching Evaluation of University ideological and political course. Chinese higher education .2011 (06)

4 Lu Jun Campus Ideological Teaching "Brain" Survey Analysis - A Case Study of Yangtze University [J] Jianghan University (Social Science Edition) .2013 (06).
} 
ideological and political education of college students on the traditional way of lost interest and peace of mind, the traditional way of education is difficult to be fully accepted students may appear rebellious extreme cases, especially in some ideological and political education workers did not realize that the "non ecology "run non-harmonious, still stick to the traditional way of teaching formalism. ${ }^{5}$

Core of the conventional concept of political education by a college or to grasp the main contents Universities spread socialism with Chinese characteristics is the main core beliefs and values, information, and gradually guide the formation of students' ideological concept, from the media led to the dissemination of information era "non school master "and gradually turned to the right to speak in University students the right to speak, to the center of the network media allow both voice generated impact, the students on the traditional single dominant mode of discourse is not satisfied, in particular in the Campus Ideological education, students learn for hot events knows more than the teacher, students are no longer satisfied with the content of school communication, which is also when the relationship between students and school increasingly strained, in order to maintain the balance of the development of this ecosystem, Universities need to actively change the volume of the conventional concept of ideological and political education, the use of new technologies from the media to bring new ideas to the reform of college ideological and political education system. ${ }^{6}$

\section{Suggestions for Improvement}

Classroom Teaching Ecology. Change the past, individual style indoctrination teaching, innovative teaching methods Campus Ideological need to do the following aspects: 1, now college students real life Ideological and Political literacy is largely reflected in daily life, so colleges and universities ideological and political education is the key Find the surrounding living environment and teaching content interoperability of the Department, based on the basic characteristics of college students health costs, the ecological classroom is the key system coordination, use of situational interaction of the classroom influence of ideology and culture, promoting the thinking fundamentally political education classroom and ecological adaptation ideological quality of students; 2 , the ideological and political classroom teaching and actively explore the development of current affairs hot events. Ecological classroom teaching is inseparable from the course to build ecological system, ecological systems continue inside information, dynamic operation of energy, information itself needs to interact via the students' self build to get. For a class of social hot issues, into the main focus of ideological and political education in colleges and universities, bring students to learn, at the same time thinking of interest, but also to enhance the students' learning in the dominant position, and promote the exchange of teachers and equality of both parties; 3 , to carry out practical issues the ideological and political education. Ideological and political education of college students thinking, learning groups have independence, teach basic theoretical subject knowledge, combined with social practice platform to enhance the participation of universities and improve their practical experience to achieve their self-development, self-education purposes; 4 , the interaction of the classroom, so that students and teachers have their good ecological position in the grid roundtable teaching of classroom teaching, based on the exchange theme of the event, which improves fundamentally students to participate in political education initiative process, reflected in student-centered education new ideas. $^{7}$

Classroom resource types, based on various courses in Universities balance resource elements of view, part of the curriculum resources from the community, school, and the other part of the campus, there is a natural resource from information technology, but also the activities of. So from the time the media Course Resource and universities to select those with the high ideological and political

\footnotetext{
${ }^{5}$ Fang Haitao College Network Status and Self-Management Pathways media management [J]. School Party and ideological education $2012(30)$

${ }^{6}$ Liu Zuo yuan, Flora Patterns of cognitive and Reflections on Students' Ideology Security Under the new media environment [J]. School Party and ideological education .2012 (03)

${ }^{7}$ Zheng Yuanjing. Effectiveness of ideological and political education in the new media environment [J]. Ideological \& Theoretical Education .2011 (11)
} 
education curriculum resource element, the contents of other methods to achieve accurate docking curriculum model to optimize the Campus Ideological Education Resources feature to achieve from the system. Including: 1, combined with the ideological and political course and humanities courses. Basically, political education also belongs to the humanities and social sciences category, the difficulty of integrating small elements, with emphasis on the integration of methods, concepts, ideas and other hidden resources. For example, the basic communication theory-based approach for network ideological and political education is combined with Marxism, particularly the integration of the concept of communication to make up for past deficiencies way of teaching indoctrination; 2 , combined with the ideological and political course and Natural Science.

The Construction of Campus Ecological Culture. Media content Campus Culture Ecology Education grasp. Since the advent of the era of the media, university personnel training as the main positions, we need to seize the opportunity to maintain a good attitude and a clear head use self-media platform to launch a new platform Campus Ideological Education. Campus Culture ecological education need a good grasp of the content to select from media platforms, universities also need to pay attention to the spread of media attention to the content selection red school site, the ideological and political education courseware, international affairs, current events and other regularly updated, all kinds of manifestations of innovation to change the past rigorous political philosophy, ethics and other core content into more shallow, multiple forms, to increase students' interest in reading the website of red. ${ }^{8}$

The school actively grasps the dominant position of the network environment. Schools need a good grasp of the dominant position of a network of ecological environment, in particular the right to speak of the network, special attention emergency mechanism of mass incidents, the school needs to improve the corresponding emergency mechanism, it is necessary to enter into self-media platform to achieve with the current College Students a total territory, find hot spots students concern for self-language media platform for dialogue, the event requires active treatment, schools need to arrange for a day dedicated staff responsible school official micro-blog and BBS forum updates, but also on the following student comments and questions were timely recovery for some unexpected events school and society emerged, good schools and good treatment response, an important event occurred in the school to do public relations crisis, the right to speak of the event. Hot social practice a unified response to treatment according to the official attitude of the school need to open the internal situation, positive, unified, coordinated principles to deal with in a timely manner some untrue statements strangled at source and promoting positive communication event handling.

\section{Acknowledgements}

College of Humanities and social science research projects in Shandong Province (Special Political and Ideological Education Research) University Ideological and Political Education Ecological Operations Research from media age; Item Number: J15YB10

\section{References}

[1] Luo Changqin from ecological Perspective Analysis of Chinese Marxism theoretical results and experience ecological evolution [J]. JOURNAL Heihe .2012 (03)

[2] Xiaoying Sheng, Zhang Yaocan New Thinking [J]. Teaching Evaluation of University ideological and political course. Chinese higher education .2011 (06)

[3] Lu Jun Campus Ideological Teaching "Brain" Survey Analysis - A Case Study of Yangtze University [J] Jianghan University (Social Science Edition) .2013 (06).

[4] Fang Haitao College Network Status and Self-Management Pathways media management [J].

\footnotetext{
${ }^{8}$ Wang Hong, Liu Peng. Over the past decade research network ideological and political education Review [J]. Teaching and Research .2011 (11)
} 
School Party and ideological education .2012 (30)

[5] Liu Zuo yuan, Flora Patterns of cognitive and Reflections on Students' Ideology Security Under the new media environment [J]. School Party and ideological education .2012 (03)

[6] Zheng Yuanjing. Effectiveness of ideological and political education in the new media environment [J]. Ideological \& Theoretical Education .2011 (11)

[7] Wang Hong, Liu Peng. Over the past decade research network ideological and political education Review [J]. Teaching and Research .2011 (11) 